TITLE:

\title{
Janus-Type Gold/Polythiophene Composites Formed via Redox Reaction at the Ionic Liquid|Water Interface
}

\section{AUTHOR(S):}

Nishi, Naoya; Yajima, Ikumi; Amano, Ken Ichi; Sakka, Tetsuo

\section{CITATION:}

Nishi, Naoya ... [et al]. Janus-Type Gold/Polythiophene Composites Formed via Redox Reaction at the Ionic Liquid|Water Interface. Langmuir 2018, 34(7): 2441-2447

\section{ISSUE DATE:}

2018-02-20

URL:

http://hdl.handle.net/2433/254672

\section{RIGHT:}

This document is the Accepted Manuscript version of a Published Work that appeared in final form in Langmuir, copyright ( $)$ American Chemical Society after peer review and technical editing by the publisher. To access the final edited and published work see https://doi.org/10.1021/acs. langmuir.7b03792.; This is not the published version. Please cite only the published version.; この論文は出版社版でありません。引用の際には出版社版をご確認で利用ください。 


\title{
Janus-type gold/polythiophene composites
}

\section{formed via redox reaction at the ionic liquid|water interface}

\author{
Naoya Nishi," Ikumi Yajima, Ken-ichi Amano, and Tetsuo Sakka \\ Department of Energy and Hydrocarbon Chemistry, Graduate School of Engineering, Kyoto \\ University, Kyoto, 615-8510, Japan \\ E-mail: nishi.naoya.7e@kyoto-u.ac.jp \\ Phone: +81 (75)383 2491
}

\begin{abstract}
Janus-type Au/polythiophene (PT) composites have been prepared by utilizing the liquid/liquid interface between water (W) and a hydrophobic ionic liquid (IL) as the redox reaction site. $\mathrm{AuCl}_{4}^{-}$are reductively deposited and terthiophene are oxidatively polymerized spacio-selectively at the IL $\mid \mathrm{W}$ interface, leading to the formation of the $\mathrm{Au} / \mathrm{PT}$ composites. The composites are Janus-type Au-attached PT plates with two surface morphologies, flat surface and flower-like surface at the W and IL sides of the plates at the IL $\mid \mathrm{W}$ interface, respectively. Not only the surface morphologies but also attached $\mathrm{Au}$ structures are different at the two surfaces; Au microurchins on the flat surface and dendritic Au nanofibers on the flower-like surface. Optical and scanning electron microscopic observation has revealed that nanofibers and microurchins are formed at the early and later stage of the reaction, respectively. Electrochemistry at the IL $\mid \mathrm{W}$ interface has illustrated that electron transfer across the IL $\mid \mathrm{W}$ interface during the formation of the Janus-type Au/PT composites is coupled with ion transfer of
\end{abstract}


$\mathrm{AuCl}_{4}^{-}$to compensate for charge unbalance in the two liquid phases. $\mathrm{AuCl}_{4}^{-}$transferred into IL is found to be the source of the dendritic Au nanofibers formed at the IL side of the PT plates.

\section{Introduction}

The oil -water two-phase system is widely known to be utilized for the formation of metal nanoparticles. Faraday used carbon disulfide-water two-phase system to make Au colloids in the 19th century. ${ }^{1}$ Another and probably the most famous example is the Brust-Schiffrin method $^{2}$ in which thiols in oil are utilized as both of reducing agent and capping reagent for the Au nanoparticles. ${ }^{3}$ When metal precursor is only dissolved in one phase and reducing agent only in the other phase, the redox reaction for the metal nanoparticle formation can be spatially limited at the oil|water $(\mathrm{O} \mid \mathrm{W})$ interface. $^{4,5}$ In such cases, the phase boundary potential across the $\mathrm{O} \mid \mathrm{W}$ interface is expected to control the reaction rate and therefore to control the size of nanoparticles. Not only metal nanoparticles but also polymer can be formed via redox reaction at the $\mathrm{O} \mid \mathrm{W}$ interface where monomer or oligomer reacts with oxidizing agent. ${ }^{6-12}$ Polymer composites of metal ${ }^{13-17}$ and carbon nanomaterials ${ }^{18-20}$ have also been reported by using the redox reaction at the $\mathrm{O} \mid \mathrm{W}$ interface.

Ionic liquids (ILs), which are liquid salts entirely composed of cations and anions, can be immiscible with water when the ions composing ILs are hydrophobic. Such a hydrophobic IL is a candidate as an alternative of oil for the oil-water two-phase system. From the viewpoint of materials chemistry, the IL-water two-phase system has been utilized as a redox-reaction site for the formation of nanostructures of $\mathrm{Au},{ }^{21-23} \mathrm{Ag},{ }^{24,25} \mathrm{Pd},{ }^{26}$ and $\mathrm{Co}^{26}$ and Ag-polypyrrole composites. ${ }^{27,28}$ We have also found that dendritic Au nanofibers are formed at the IL $\mid \mathrm{W}$ interface, utilizing the spacio-selective redox reaction between metal ion in $\mathrm{W}$ and reducing agent in IL at the IL $\mid \mathrm{W}$ interface. ${ }^{22,29}$ The redox reaction occurs at the two-dimensional IL $\mid \mathrm{W}$ interface, however, the formed nanostructures, dendritic Au nanofibers, have one-dimensional morphology. This intriguing geometry mismatch has been 
discussed with two characteristics of ILs: high viscosity on the order of Pa s and specific interfacial structure, ionic multilayers, ${ }^{30,31}$ both of which seem to affect growing rate and direction of $\mathrm{Au}$ nanostructures. ${ }^{22,29}$

In the present study, we extend the above-mentioned method, the formation of metal nanostructures via redox reaction at the IL $\mid \mathrm{W}$ interface, to the formation of Janus-type metal-polymer composites. It was achieved via redox reaction at the IL $\mid \mathrm{W}$ interface where $\mathrm{AuCl}_{4}^{-}$in $\mathrm{W}$ is reductively deposited and 2,2':5',2"-terthiophene $\left(\mathrm{T}_{3}\right)$ is oxidatively polymerized to polythiophene (PT), simultaneously. Previous studies reported that at the $\mathrm{O} \mid \mathrm{W}$ interface composites of $\mathrm{Au}$ and 3,4-ethylenedioxythiophene can be formed. ${ }^{15,16} \mathrm{Au} / \mathrm{PT}$ composites have been studied for the applications to $\mathrm{pH}$ sensor, ${ }^{32}$ biosensor, ${ }^{33,34}$ and catalyst. ${ }^{35}$ For the preparation of Janus structures, the $\mathrm{O} \mid \mathrm{W}$ interface, in either case of macro-sized flat one or micro-sized curved one at the surface of micelles and emulsions, has intensively been used. ${ }^{36-38}$ Toth et al. used redox reaction at the $\mathrm{O} \mid \mathrm{W}$ interface to prepare Janus metal-graphene nanocomposites, by selectively depositing metal nanostructures on one side of graphene adsorbed at the $\mathrm{O} \mid \mathrm{W}$ interface. ${ }^{39}$ Not only the redox reaction but also hydrolysis, ${ }^{40,41}$ crosslinking, ${ }^{42}$ ligand exchange, ${ }^{43}$ and particle surface modification ${ }^{44}$ reactions have been developed for the preparation of a wide variety of Janus structures at the $\mathrm{O} \mid \mathrm{W}$ in-

terface. The present paper reports the use of the IL $\mid \mathrm{W}$ interface as the preparation site of Janus structures. Note that there are some studies using ILs as the components of Janus structures. ${ }^{45-47}$ We will show in the present study that the reaction mechanism for the formation of the Janus-type Au/PT composites at the IL/W interface and how to control their anisotropy.

\section{Experimental}

A highly hydrophobic IL, trioctylmethylammonium bis(nonafluorobutanesulfonyl)amide $\left(\left[\mathrm{TOMA}^{+}\right]\left[\mathrm{C}_{4} \mathrm{C}_{4} \mathrm{~N}^{-}\right]\right)$, was used unless otherwise noted. [TOMA $\left.{ }^{+}\right]\left[\mathrm{C}_{4} \mathrm{C}_{4} \mathrm{~N}^{-}\right]$was prepared ${ }^{48}$ 
and purified ${ }^{49,50}$ similarly to the method reported previously. The experimental condition for the formation of $\mathrm{Au} / \mathrm{PT}$ composites at the IL/W interface is similar to the one for dendritic Au nanofibers in our previous study, ${ }^{22}$ except for the reducing agent. $\mathrm{T}_{3}$ (Sigma-Aldrich), a reducing agent in the present study, was dissolved in IL. $\mathrm{HAuCl}_{4}$ and $\mathrm{T}_{3}$, which are dissolved in $\mathrm{W}$ and IL, respectively, do not partition into the other liquid phase. This solubility constraints make the electron transfer (ET) between $\mathrm{AuCl}_{4}^{-}$and $\mathrm{T}_{3}$ occur only at the IL $\mid \mathrm{W}$ interface. However, $\mathrm{AuCl}_{4}^{-}$(not $\mathrm{HAuCl}_{4}$ ) is driven to be transferred into IL, i.e., the ion transfer (IT) occurs, by electrochemical motive force generated by ET, which led to the formation of the Janus-type Au decorated PT in the present study (see Results and Discussion).

ET and IT across the IL $\mid \mathrm{W}$ interface, which constitutes the formation reaction of the $\mathrm{Au} / \mathrm{PT}$ composites, was electrochemically measured. A micropipette filled with W was immersed in IL to form the micro-sized IL $\mid \mathrm{W}$ interface at the tip (inner diameter: $10 \mu \mathrm{m}$ ) of the micropipette. ${ }^{51-53}$ The two-electrode electrochemical cell employed is:

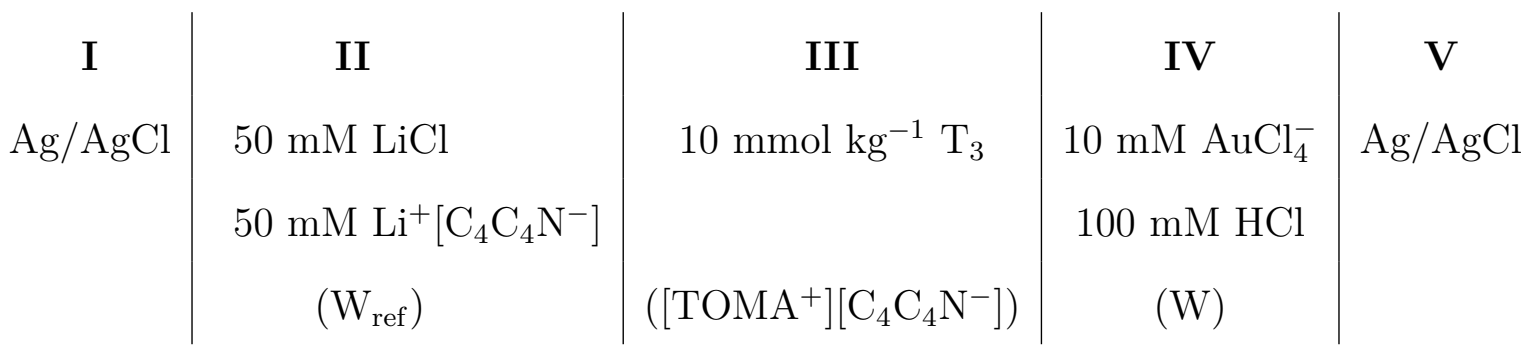

(Cell I)

where $\mathrm{M}$ denotes mol dm${ }^{-3}$. As a counter/reference electrode, a glass cylinder filled with $\mathrm{W}_{\text {ref }}$ (phase II) was also immersed in IL. $\mathrm{Ag} / \mathrm{AgCl}$ (phases I and V) wires were inserted into the micropipette and the glass cylinder. The voltage, $E$, was applied to the right-hand-side terminal (phase V) with respect to the left (phase I). The current $I$ due to the transfer of cations from $\mathrm{W}$ to $\left[\mathrm{TOMA}^{+}\right]\left[\mathrm{C}_{4} \mathrm{C}_{4} \mathrm{~N}^{-}\right]$is taken to be positive.

The above system (Cell I) records current due to both of ET and IT across the IL|W interface. In order to analyze only ET we adopted ECSOW (electron-conductor separating 
oil-water) system, ${ }^{22,54,55}$ where the liquid-liquid interface is separated by electron conductor to prevent IT. In the present case for the IL $\mid \mathrm{W}$ interface the electrochemical cell is as follows

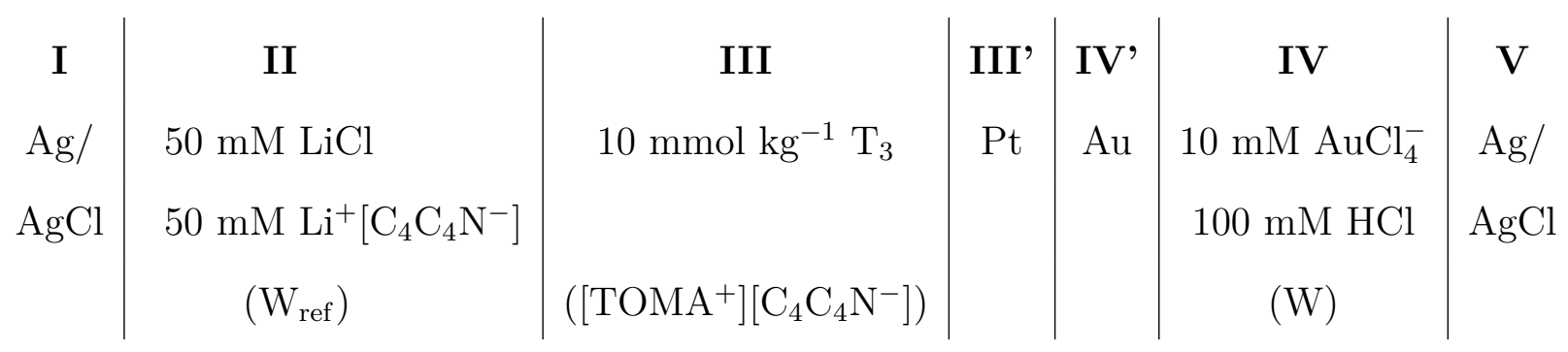

(Cell II)

In Cell II, we immersed Au wire (phase IV') into W (phase IV) and immersed Pt microelectrode with a tip diameter of $10 \mu \mathrm{m}$ (phase III') into $\left[\mathrm{TOMA}^{+}\right]\left[\mathrm{C}_{4} \mathrm{C}_{4} \mathrm{~N}^{-}\right]$(phase III). The Au wire and the Pt microelectrode were electrically connected by a lead wire. Since the area of the Pt|IL interface is several order of magnitudes smaller than the $\mathrm{Au} \mid \mathrm{W}$ interface, the recorded current is limited by processes for ET at Pt|IL interface (mass transfer and redox of $\mathrm{T}_{3}$ ). For the measurements with Cells I and II, a potentiostat (HECS972 with the headbox 972-1, Fuso) was used and the temperature was controlled at $25.0^{\circ} \mathrm{C}$ by circulating water in the jacket of the cells from a water bath.

In order to investigate the morphology of the $\mathrm{Au} / \mathrm{PT}$ composites formed at the IL $\mid \mathrm{W}$ interface, macro-sized IL|W interface was formed by filling a glass bottle (inner diameter: $12 \mathrm{~mm}$ ) with $0.38 \mathrm{~g}$ of IL containing $10 \mathrm{mmol} \mathrm{kg}{ }^{-1} \mathrm{~T}_{3}$ (phase III) and $1.15 \mathrm{~g}$ of $\mathrm{W}$ containing $10 \mathrm{mM} \mathrm{AuCl}_{4}^{-}$(phase IV). The sample was left for 7 days at room temperature. The obtained deposits (black film) were collected and suspended in methanol. The suspension was centrifuged and the supernatant was removed. This washing procedure was repeated three time and the deposits were dried in air. The nanostructures on a carbon tape are observed by scanning electron microscope (SEM, ultra-55, Zeiss) equipped with energy dispersive x-ray spectrometer (EDX). The morphology of the composites did not change with or without centrifugation. To investigate the deposition process of the composites at the IL/W 
interface, we performed in-situ optical microscopic observation of the IL|W interface and SEM observation of "quenched" deposits. For the former, an optical microscope (BX51M, Olympus) equipped with $2 \mathrm{x}$ objective lens was used to observe the IL/W interface from the top (from $\mathrm{W}$ side). For the latter, the sample was retrieved from the two-phase system at several stages after the contact of the two phases and observed by SEM.

\section{Results and Discussion}

In the two-phase IL-W system containing $\mathrm{T}_{3}$ in IL and $\mathrm{AuCl}_{4}^{-}$in $\mathrm{W}$, deposits (black film) were spontaneously formed, indicating that ET across the IL $\mid \mathrm{W}$ interface occurred. ET across the IL|W interface was electrochemically measured using Cell II. Fig.1a shows the CVs for ET. Note that in this measurements IL and W are separated by metal electrodes so that we can detect ET but not IT across the IL|W interface. One can see positive current due to ET from IL to W during the positive-going scan. ET from IL to W corresponds to the combination of the following two half-reactions at the W and IL sides of the interface, respectively

$$
\begin{aligned}
\mathrm{AuCl}_{4}^{-}(\mathrm{W})+3 \mathrm{e}^{-} & \rightarrow \mathrm{Au}(\sigma)+4 \mathrm{Cl}^{-}(\mathrm{W}) \\
n \mathrm{~T}_{3}(\mathrm{IL}) & \rightarrow \mathrm{PT}(\sigma)+2 n \mathrm{H}^{+}(\mathrm{IL})+2 n \mathrm{e}^{-}
\end{aligned}
$$

where $\sigma$ denotes the interface. In the negative-going scan of the CVs, negative current due to backward reactions of eqs 1 and 2 is discernible. Both of the positive and negative current increase with increasing the cycle number of CVs as shown in Fig.1a. This is because PT, which is redox-active polymer ${ }^{56}$ and generated by the oxidation of $\mathrm{T}_{3}$ in eq 2 , forms the film on the Pt electrode ${ }^{57}$ and joins ET via doping/dedoping of anions as follows;

$$
\mathrm{PT}(\sigma)+m \mathrm{C}_{4} \mathrm{C}_{4} \mathrm{~N}^{-}(\mathrm{IL}) \rightleftharpoons \mathrm{PT}^{m+} \cdot m \mathrm{C}_{4} \mathrm{C}_{4} \mathrm{~N}^{-}(\sigma)+m \mathrm{e}^{-}
$$


where $m$ is the number of the doped anions in PT. Note that ET never individually proceeds without the help of either electrochemical instruments or other coupled charge transfer that can cancel out the charge unbalance in W and IL caused by ET. The spontaneous formation of the deposits in the IL-W two-phase system indicates that other charge transfer should be coupled with ET shown in eqs 1-3. We investigated the coupled charge transfer across the IL $\mid \mathrm{W}$ interface.

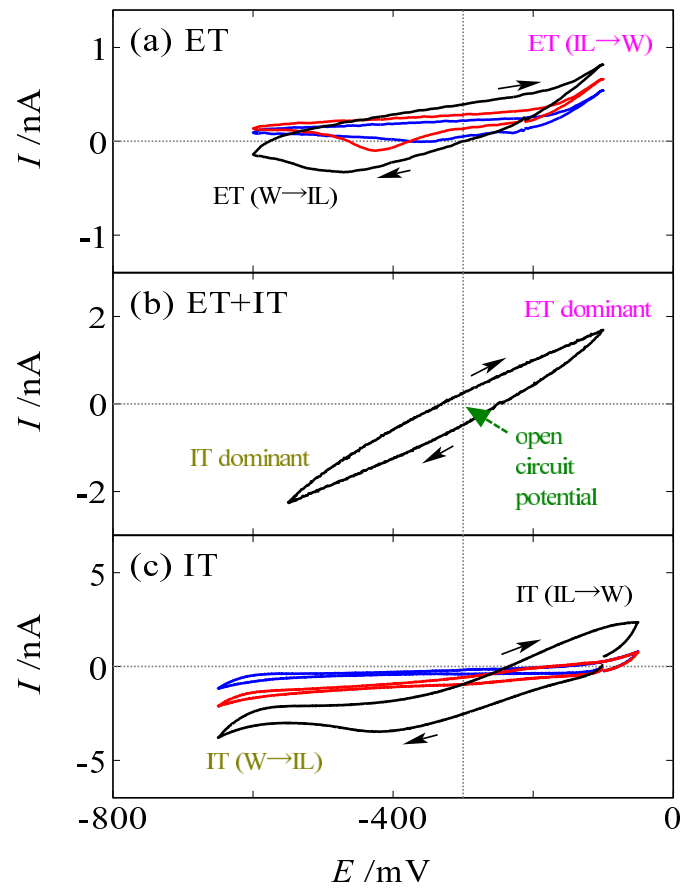

Figure 1: Cyclic voltammograms at the IL|W interface (a) for the ET using Cell II at 2nd cycle (blue), 10th cycle (red), 15th cycle (black), (b) for the IT and ET using Cell I, (c) for the IT using Cell I but without $\mathrm{T}_{3}$ in IL and with 0 (blue), 1 (red), and 10 (black) $\mathrm{mM}$ $\mathrm{AuCl}_{4}^{-1}$ in W. Scan rate: $100 \mathrm{mV} \mathrm{s}^{-1}$.

Figure 1b shows a CV at the IL|W interface without blocking IT using Cell I, where both ET and IT occur. One can see almost linear shape in the CV, which means nonpolarized behavior composed of the currents of two charge transfers with opposite sign. ${ }^{58}$ The open circuit potential (OCP), at which net current is zero, is around $-300 \mathrm{mV}$ and the spontaneous reaction for the formation of the deposits proceeds at OCP. The positive current in Fig.1b originates from ET as one can see positive current rise due to ET at potentials more positive 
than OCP in Fig.1a. The positive current is compensated for by negative current due to other charge transfer, resulting in the nonpolarized CV in Fig.1b.

Two candidates can be considered as the charge transfer that generates the negative current in Fig.1b. One is IT of $\mathrm{H}^{+}$, which is generated via eq 2, from IL to W

$$
\mathrm{H}^{+}(\mathrm{IL}) \rightarrow \mathrm{H}^{+}(\mathrm{W})
$$

The other is IT of $\mathrm{AuCl}_{4}^{-}$from $\mathrm{W}$ to IL

$$
\mathrm{AuCl}_{4}^{-}(\mathrm{W}) \rightarrow \mathrm{AuCl}_{4}^{-}(\mathrm{IL})
$$

as was the case for the formation of dendritic $\mathrm{Au}$ nanofibers at the IL $\mid \mathrm{W}$ interface. ${ }^{22}$ In Fig.1c shown are the CVs for IT of $\mathrm{AuCl}_{4}^{-}$measured using Cell I without $\mathrm{T}_{3}$ in IL. One can see negative current at potentials more negative than OCP $(-300 \mathrm{mV})$. To examine how much the former candidate, IT of $\mathrm{H}^{+}$(eq 4), possibly contributes to the coupling with ET, we performed a control experiment. We prepared tetraoctylammonium $\mathrm{AuCl}_{4}^{-},{ }^{55}$ a salt with hydrophobic cation, and dissolved it in IL instead of dissolving $\mathrm{HAuCl}_{4}$ in $\mathrm{W}$ for the formation of $\mathrm{Au} / \mathrm{PT}$ in a glass bottle. In that case, IT of $\mathrm{AuCl}_{4}^{-}$in eq 5 does not occur because $\mathrm{AuCl}_{4}^{-}$ions are initially in IL. If IT of $\mathrm{H}^{+}$is coupled with ET, ET and IT would spontaneously proceed in the glass-bottle experiment. As a result, we were not able to obtain any deposits, suggesting that ions for IT coupled with ET is not $\mathrm{H}^{+}$but $\mathrm{AuCl}_{4}^{-}$. Although it is uncertain how the generated $\mathrm{H}^{+}$ions, which is generally highly hydrophilic, ${ }^{59}$ are stabilized in IL, they presumably exist around anions in IL: $\mathrm{C}_{4} \mathrm{C}_{4} \mathrm{~N}^{-}$(IL-anion) or $\mathrm{AuCl}_{4}^{-}$. Summarizing the electrochemical experiments to reveal the reaction mechanism, ET (eqs 13) and IT of $\mathrm{AuCl}_{4}^{-}$(eq 5) are found to simultaneously occur for the spontaneous formation of the $\mathrm{Au} / \mathrm{PT}$ composites. As will be discussed below, IT of $\mathrm{AuCl}_{4}^{-}$is an important process not only because it cancels out the charge unbalance caused by ET, but also because it is essential to form Au nanofibers in IL. 
We formed a two-phase IL-W system containing $\mathrm{AuCl}_{4}^{-}$in $\mathrm{W}$ and $\mathrm{T}_{3}$ in IL and analyzed deposits that were spontaneously formed at the IL|W interface. From the SEM observation, it was found that deposits are plates having two surface morphologies. Two SEM images for the two surface morphologies are shown in Fig.2. Figure 2a shows flat surface on which urchin-like structures with a size of 10-30 $\mu \mathrm{m}$ are attached (see Fig.S1 for the magnified SEM image). The other SEM image in Fig.2b is for flower-like surface on which one can see dendritic nanofibers with a diameter of 50-100 $\mathrm{nm}$ and a length of more than $8 \mu \mathrm{m}$. In the EDX analysis the elements $\mathrm{C}$ and $\mathrm{S}$ were detected for the plate and $\mathrm{Au}$ was detected for the attached structures (Figs.S2 and S3), indicating that the deposits are PT plates having flat and flower-like surfaces on which Au microurchins and dendritic Au nanofibers are attached, respectively. In the EDX analysis $\mathrm{O}, \mathrm{F}, \mathrm{Au}, \mathrm{Cl}$ were also detected for the PT plate (Fig.S4), indicating that not only $\mathrm{C}_{4} \mathrm{C}_{4} \mathrm{~N}^{-}$(eq 3) but also $\mathrm{AuCl}_{4}^{-}$are doped into the PT via its oxidation. The half-reaction equation for the latter is as follows.

$$
\mathrm{PT}(\sigma)+m \mathrm{AuCl}_{4}^{-}(\mathrm{W}) \rightleftharpoons \mathrm{PT}^{m+} \cdot m \mathrm{AuCl}_{4}^{-}(\sigma)+m \mathrm{e}^{-}
$$

The doping of $\mathrm{AuCl}_{4}^{-}$into PT was reported to stabilize PT structures. ${ }^{60,61}$ The doping reaction is another charge-compensation reaction than IT of $\mathrm{AuCl}_{4}^{-}$in the later stage of the formation of the Au/PT composites as will be discussed below.

It is natural to think that the two surface morphologies stem from the geometrical and physicochemical heterogeneity of the IL $\mid \mathrm{W}$ interface, where the deposition reaction proceeds. To confirm which of the flat and flower-like surfaces faces to the IL and W sides of the IL $\mid \mathrm{W}$ interface, we used another hydrophobic IL, trioctylmethylammonium tetrakis[3,5bis(trifluoromethyl)phenyl]borate $\left(\left[\mathrm{TOMA}^{+}\right]\left[\mathrm{TFPB}^{-}\right]\right)$, that has melting point higher than room temperature $\left(36^{\circ} \mathrm{C}\right){ }^{?}$ During the deposition, the temperature for the IL-W two-phase system was kept at $50{ }^{\circ} \mathrm{C}$ where $\left[\mathrm{TOMA}^{+}\right]\left[\mathrm{TFPB}^{-}\right]$is liquid. After the completion of the deposition the temperature was lowered to room temperature and $\left[\mathrm{TOMA}^{+}\right]\left[\mathrm{TFPB}^{-}\right]$was 


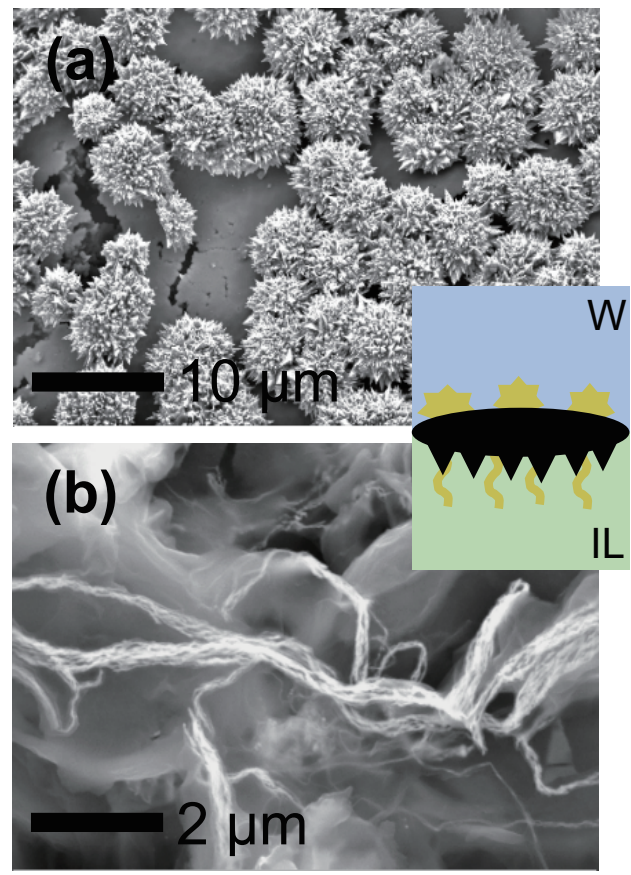

Figure 2: SEM images of the Janus-type Au/PT composites for (a) the W side with Au microurchins and (b) the IL side with dendritic Au nanofibers.

solidified by keeping the orientation of the deposition at the IL $\mid \mathrm{W}$ interface. The $\mathrm{W}$ phase was removed and the surface of the deposits on the solidified $\left[\mathrm{TOMA}^{+}\right]\left[\mathrm{TFPB}^{-}\right]$was observed with SEM. The SEM observation revealed that the W side of the Au/PT composites has flat surface with Au microurchins (Fig.S5). On the other hand, both of the two surface morphologies were observed in the SEM images for the deposits after the washing procedure without keeping the orientation of the composites, as is the case for $\left[\mathrm{TOMA}^{+}\right]\left[\mathrm{C}_{4} \mathrm{C}_{4} \mathrm{~N}^{-}\right]$in Fig.2. These observations suggest that the IL side of the Au/PT composites is the flower-like surface with dendritic Au nanofibers. Therefore, the deposits are found to be Janus-type $\mathrm{Au} / \mathrm{PT}$ composites formed at the IL|W interface as schematically shown in Fig.2.

To further investigate the deposition process we performed in-situ optical microscopic observation of the IL|W interface and SEM observation of "quenched" deposits. In the optical microscopic observation, black film, PT plates, appeared on the IL $\mid \mathrm{W}$ interface after 


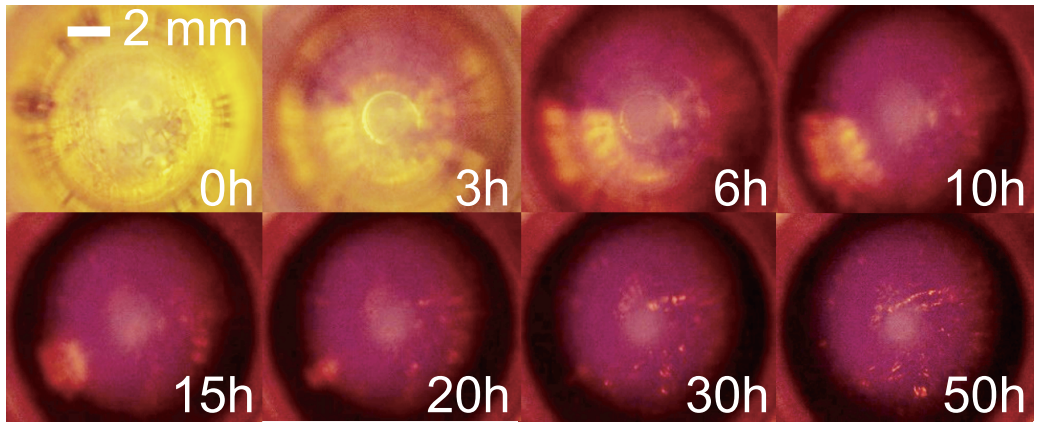

Figure 3: Optical microscopic images of the IL $\mid \mathrm{W}$ interface observed from the top (W side) at several stages after the contact of the two phases.

the contact of the two phases and the area increased with increasing time (Fig.3). The film fully covered the IL $\mid \mathrm{W}$ interface in $30 \mathrm{~h}$. We also took SEM images of the deposits retrieved from the two-phase system at 20,30, and $50 \mathrm{~h}$ after the contact of the two phases. The $\mathrm{Au}$ microurchins on the flat surface are scarce at $20 \mathrm{~h}$ and increased the number and size with increasing time (Fig.4), whereas dendritic Au nanofibers were already observed at 20 $\mathrm{h}$ and did not increase their number and density much. From these results, the formation mechanism of the Janus-type Au/PT composites is schematically drawn in Fig.5. In the first stage, ET occurs, producing seeds of PT and Au at the IL $\mid \mathrm{W}$ interface (Fig.5a). IT of $\mathrm{AuCl}_{4}^{-}$is coupled with $\mathrm{ET}$, resulting in the increase in the $\mathrm{AuCl}_{4}^{-}$concentration at the IL side of the IL $\mid \mathrm{W}$ interface. In the second stage until around $20 \mathrm{~h}$ (Fig.5b), ET and IT keep proceeding, with PT growing along with the IL|W interface to form flat surface at the W side and also flower-like surface at the IL side. $\mathrm{AuCl}_{4}^{-}$in IL is reduced to be dendritic $\mathrm{Au}$ nanofibers,

$$
\mathrm{AuCl}_{4}^{-}(\mathrm{IL})+3 \mathrm{e}^{-} \rightarrow \mathrm{Au}(\sigma)+4 \mathrm{Cl}^{-}(\mathrm{IL})
$$



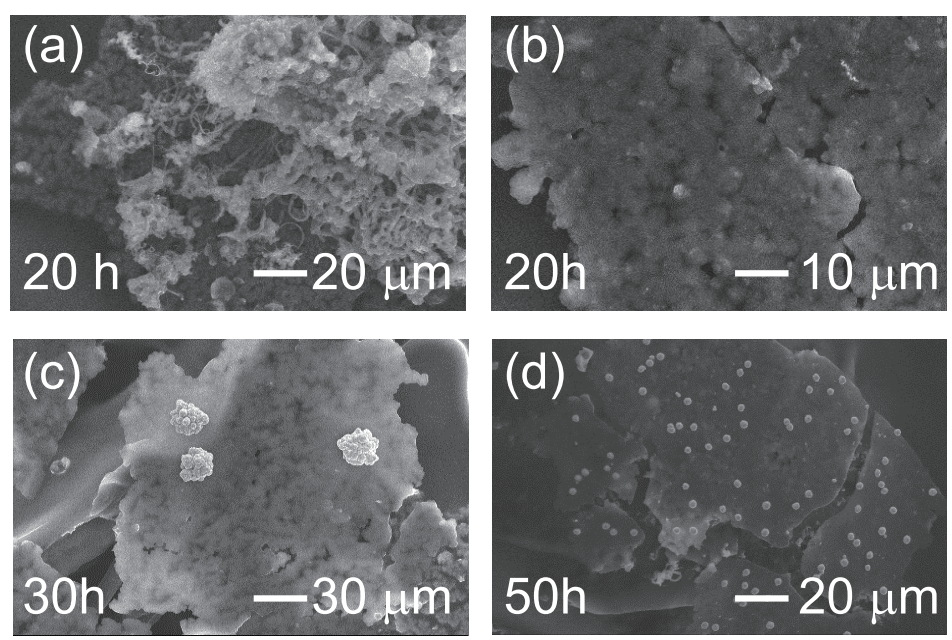

Figure 4: SEM images for the (a) flower-like and (b-d) flat surfaces of PT plates retrieved during the reaction from the two-phase system at (a,b) 20, (c) 30, and (d) $50 \mathrm{~h}$.

followed by the release of $\mathrm{Cl}^{-}$to $\mathrm{W}$.

$$
\mathrm{Cl}^{-}(\mathrm{IL}) \rightarrow \mathrm{Cl}^{-}(\mathrm{W})
$$

The combination of these two processes with IT of $\mathrm{AuCl}_{4}^{-}$(eq 5) leads to the half-reaction of eq 1. This indicates the importance of the transfer of $\mathrm{Cl}^{-}$; the transfer of this hydrophilic anion $^{59}$ from hydrophobic IL to $\mathrm{W}$ decreases the Gibbs energy for ET and therefore makes ET occur at moderate potentials as shown in Fig.1a. In other words, ET without the transfer of $\mathrm{Cl}^{-}$cannot be coupled with IT of $\mathrm{AuCl}_{4}^{-}$and does not occur spontaneously. In the third stage around 30-50 h, PT fully covers the IL/W interface and block IT of $\mathrm{AuCl}_{4}^{-}$, facilitating $\mathrm{AuCl}_{4}^{-}$reduced at the $\mathrm{W}$ side of the interface (Fig.5c). From the observation, ET continued even after the block of IT of $\mathrm{AuCl}_{4}^{-}$, which is the charge compensation process against ET. The charge compensation without IT of $\mathrm{AuCl}_{4}^{-}$is likely to be attained by $\mathrm{AuCl}_{4}^{-}$doping into PT from W (eq 6), which is supported by the EDX analysis of the composites (Fig.S4). This reaction can be coupled with and drive the reduction of $\mathrm{AuCl}_{4}^{-}$(eq 1), making $\mathrm{Au}$ 
microurchins growing on the $\mathrm{W}$ side of the PT plates. In the final stage until around 170 $\mathrm{h}$, the concentration of $\mathrm{AuCl}_{4}^{-}$in $\mathrm{W}$ decreases and the mass transfer of $\mathrm{AuCl}_{4}^{-}$from W bulk to the interface becomes slow and diffusion-limited, leading to dendritic growth of Au microurchins on the flat surface of PT (Fig.5d).

$$
\text { (a) } \sim 0 \mathrm{~h}
$$

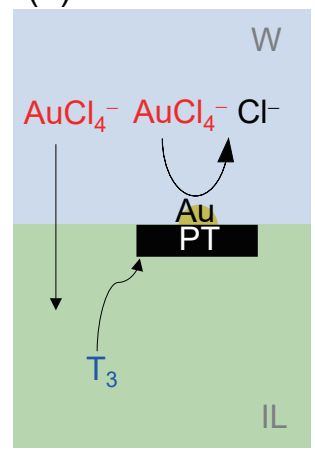

(b) $\sim 20 \mathrm{~h}$

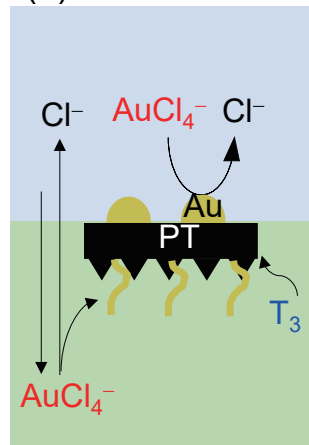

(c) $30 \sim 50 \mathrm{~h}$

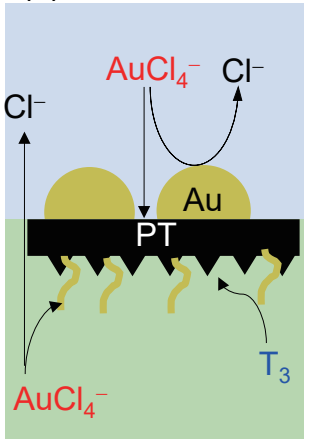

(d) $\sim 170 \mathrm{~h}$

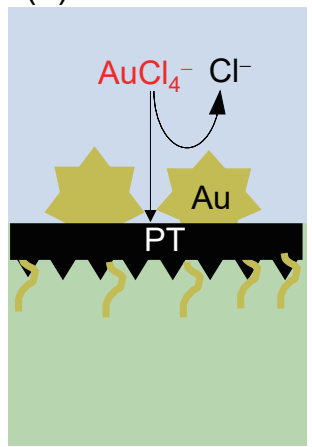

Figure 5: Schematics of the reaction mechanism for the formation of Au/PT composites at (a) 0, (b) 20, (c) 30-50, and (c) $170 \mathrm{~h}$.

Finally, we explored the possibility to make PT planes having Au structures only at one side of the plates, as is the case with a study on polymer plates for micro-motors in which Pt nanoparticles are attached only on one side of the plate. ${ }^{62} \mathrm{PT}$ planes having dendritic $\mathrm{Au}$ nanofibers on the flower-like plane only (without Au microurchins on the flat surface) was already realized by retrieving the $\mathrm{Au} / \mathrm{PT}$ composites during the reaction at $20 \mathrm{~h}$ (Fig.S7). This can be explained by the mechanism proposed above; dendritic Au nanofibers are formed at the early stage, whereas Au microurchins are formed at the later stage (Fig.3). The formation of another type of the Janus-type Au/PT composites, PT plates having $\mathrm{Au}$ microurchins on the flat surface, was also possible. This was accomplished by adding $\mathrm{Li}^{+}\left[\mathrm{C}_{4} \mathrm{C}_{4} \mathrm{~N}^{-}\right]$in $\mathrm{W} . \mathrm{C}_{4} \mathrm{C}_{4} \mathrm{~N}^{-}$is more hydrophobic than $\mathrm{AuCl}_{4}^{-}$; the former determines the positive limit of the potential window in Fig.1c, having mid-point potential for the transfer beyond the positive limit whereas the latter transfers across the IL/W interface within the potential window (more hydrophobic anion has more positive mid-point potential in the 
present definition). When $\mathrm{C}_{4} \mathrm{C}_{4} \mathrm{~N}^{-}$is present in $\mathrm{W}, \mathrm{C}_{4} \mathrm{C}_{4} \mathrm{~N}^{-}$transfers into IL instead of $\mathrm{AuCl}_{4}^{-}$during the deposition process, preventing IT of $\mathrm{AuCl}_{4}^{-}$. The formed composites showed Au only on the flat surface with the morphology of microurchins but no Au on the flower-like surface (Fig.S6). This result illustrates that IT of $\mathrm{AuCl}_{4}^{-}$is a critical process to make dendritic Au nanofibers, even without PT as our previous study. ${ }^{22}$

\section{Conclusions}

In conclusion, the present study showed that the IL|W interface can be a redox reaction site for the formation of Janus-type composites. One of possible applications of the Au/PT composites is substrates for surface-enhanced Raman scattering (SERS)-based sensors and diagnostics. Synergistic SERS enhancing effect has been recently reported for thiophene oligomer film having flower-like surface morphology on which $\mathrm{Au}$ nanoparticles are attached. ${ }^{63} \mathrm{Au}$ in the $\mathrm{Au} / \mathrm{PT}$ composites would be replaced by $\mathrm{Pt}$ or $\mathrm{Pd}$ for the catalyst applications, by applying the preparation system of $\mathrm{Pt}$ and $\mathrm{Pd}$ nanofibers at the IL/W interface that we have recently developed. Because the stages at which Au microurchins and dendritic Au nanofibers are formed are different, the formation of Janus-type bimetal sandwiches of PT would also be possible, as was realized for bimetal sandwiches of graphene formed at the $\mathrm{O} \mid \mathrm{W}$ interface. ${ }^{39,64}$

\section{Acknowledgement}

This work was partly supported by JSPS KAKENHI (Nos. 26410149, 26248004, 16H04216).

\section{Supporting Information Available}

The Supporting Information is available free of charge on the ACS Publications website at

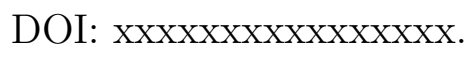


- Additional SEM images and EDX analysis for the Au/PT composites. 


\section{References}

(1) Faraday, M. The Bakerian lecture: experimental relations of gold (and other metals) to light. Phil. Trans. R. Soc. Lond. 1857, 147, 145-181.

(2) Brust, M.; Walker, M.; Bethell, D.; Schiffrin, D.; Whyman, R. Synthesis of thiolderivatized gold nanoparticles in a 2-phase liquid-liquid system. J. Chem. Soc.-Chem. Commun. 1994, 801-802.

(3) Uehara, A.; Booth, S. G.; Chang, S. Y.; Schroeder, S. L. M.; Imai, T.; Hashimoto, T.; Mosselmans, J. F. W.; Dryfe, R. A. W. Electrochemical insight into the Brust-Schiffrin synthesis of Au nanoparticles. J. Am. Chem. Soc. 2015, 137, 15135-15144.

(4) Cheng, Y.; Schiffrin, D. Electrodeposition of metallic gold clusters at the water/1,2dichloroethane interface. J. Chem. Soc.-Faraday Trans. 1996, 92, 3865-3871.

(5) Trojánek, A.; Langmaier, J.; Samec, Z. Random nucleation and growth of Pt nanoparticles at the polarised interface between two immiscible electrolyte solutions. J. Electroanal. Chem. 2007, 599, 160-166.

(6) Cunnane, V.; Evans, U. Formation of oligomers of methyl- and phenyl-pyrrole at an electrified liquid/liquid interface. Chem. Commun. 1998, 2163-2164.

(7) Maeda, K.; Janchenova, H.; Lhotsky, A.; Stibor, I.; Budka, J.; Marecek, V. Formation of a polymer layer from monomers adsorbed at a liquid|liquid interface. J. Electroanal. Chem. 2001, 516, 103-109.

(8) Gorgy, K.; Fusalba, F.; Evans, U.; Kontturi, K.; Cunnane, V. Electropolymerization of 2,2':5',2" terthiophene at an electrified liquid-liquid interface. Synth. Met. 2002, 125, 365-373.

(9) Huang, J.; Virji, S.; Weiller, B.; Kaner, R. Polyaniline nanofibers: Facile synthesis and chemical sensors. J. Am. Chem. Soc. 2003, 125, 314-315. 
(10) Nuraje, N.; Su, K.; Yang, N.-L.; Matsui, H. Liquid/liquid interfacial polymerization to grow single crystalline nanoneedles of various conducting polymers. ACS Nano 2008, 2, 502-506.

(11) Shen, M.; Han, Y.; Lin, X.; Ding, B.; Zhang, L.; Zhang, X. Preparation and electrochemical performances of porous polypyrrole film by interfacial polymerization. J. Appl. Polym. Sci. 2013, 127, 2938-2944.

(12) Anothumakkool, B.; Soni, R.; Bhange, S. N.; Kurungot, S. Novel scalable synthesis of highly conducting and robust PEDOT paper for a high performance flexible solid supercapacitor. Energy Environ. Sci. 2015, 8, 1339-1347.

(13) Johans, C.; Clohessy, J.; Fantini, S.; Kontturi, K.; Cunnane, V. Electrosynthesis of polyphenylpyrrole coated silver particles at a liquid-liquid interface. Electrochem. Commun. 2002, 4, 227-230.

(14) Knake, R.; Fahmi, A.; Tofail, S. A. M.; Clohessy, J.; Mihov, M.; Cunnane, V. J. Electrochemical nucleation of gold nanoparticles in a polymer film at a liquid-liquid interface. Langmuir 2005, 21, 1001-1008.

(15) Lu, G.; Li, C.; Shen, J.; Chen, Z.; Shi, G. Preparation of highly conductive gold-poly(3,4-ethylenedioxythiophene) nanocables and their conversion to poly(3,4ethylenedioxythiophene) nanotubes. J. Phys. Chem. C 2007, 111, 5926-5931.

(16) Harish, S.; Mathiyarasu, J.; Phani, K. L. N. Generation of gold-PEDOT nanostructures at an interface between two immiscible solvents. Mater. Res. Bull. 2009, 44, 1828-1833.

(17) Gniadek, M.; Malinowska, S.; Rapecki, T.; Stojek, Z.; Donten, M. Synthesis of polymermetal nanocomposites at liquid-liquid interface supported by ultrasonic irradiation. Synth. Met. 2014, 187, 193-200. 
(18) Salvatierra, R. V.; Oliveira, M. M.; Zarbin, A. J. G. One-pot synthesis and processing of transparent, conducting, and freestanding carbon nanotubes/polyaniline composite films. Chem. Mat. 2010, 22, 5222-5234.

(19) Domingues, S. H.; Salvatierra, R. V.; Oliveirab, M. M.; Zarbin, A. J. G. Transparent and conductive thin films of graphene/polyaniline nanocomposites prepared through interfacial polymerization. Chem. Commun. 2011, 47, 2592-2594.

(20) Toth, P. S.; Rabiu, A. K.; Dryfe, R. A. W. Controlled preparation of carbon nanotubeconducting polymer composites at the polarisable organic/water interface. Electrochem. Commun. 2015, 60, 153-157.

(21) Kaminska, I.; Niedziolka-Jonsson, J.; Roguska, A.; Opallo, M. Electrodeposition of gold nanoparticles at a solid|ionic liquid|aqueous electrolyte three-phase junction. Electrochem. Commun. 2010, 12, 1742-1745.

(22) Nishi, N.; Kakinami, T.; Sakka, T. Dendritic nanofibers of gold formed by the electron transfer at the interface between water and a highly hydrophobic ionic liquid. Chem. Commun. 2015, 51, 13638-13641.

(23) Yao, K.; Huang, Q.; Lu, W.; Xu, A.; Li, X.; Zhang, H.; Wang, J. A facile synthesis of gold micro/nanostructures at the interface of 1,3-dibutylimidazolium bis(trifluoromethylsulfonyl)imide and water. J. Colloid Interface Sci. 2016, 480, 30-38.

(24) Yao, K.; Lu, W.; Li, X.; Wang, J.; Yuan, J. Tunable synthesis of Ag films at ionic liquid-aqueous interfaces. Chem. Commun. 2013, 49, 1398-1400.

(25) Yao, K.; Li, Z.; Li, X.; Lu, W.; Xu, A.; Zhang, H.; Wang, J. Tunable synthesis of Ag films at the interface of ionic liquids and water by changing cationic structures of ionic liquids. Cryst. Growth Des. 2017, 17, 990-999. 
(26) Chen, Y.; Chen, M.; Shi, J.; Yang, J.; Zhang, D. Fabrication of "clean" nano-structured metal materials on ionic liquid/water interface. Mater. Lett. 2014, 132, 153-156.

(27) Wei, Y.; Li, L.; Yang, X.; Pan, G.; Yan, G.; Yu, X. One-step UV-induced synthesis of polypyrrole/Ag nanocomposites at the water/ionic liquid interface. Nanoscale Res. Lett. 2010, 5, 433-437.

(28) Yang, X.; Li, L.; Shang, S.; Pan, G.; Yu, X.; Yan, G. Facial synthesis of polypyrrole/silver nanocomposites at the water/ionic liquid interface and their electrochemical properties. Mater. Lett. 2010, 64, 1918-1920.

(29) Kakinami, T.; Nishi, N.; Amano, K.-i.; Sakka, T. Preparation of dendritic gold nanofibers using a redox reaction at the interface between an ionic liquid and water: correlation between viscosity and nanostructure. Bunseki Kagaku 2016, 65, 157-161.

(30) Mezger, M.; Schröder, H.; Reichert, H.; Schramm, S.; Okasinski, J. S.; Schöder, S.; Honkimäki, V.; Deutsch, M.; Ocko, B. M.; Ralston, J.; Rohwerder, M.; Stratmann, M.; Dosch, H. Molecular layering of fluorinated ionic liquids at a charged sapphire (0001) surface. Science 2008, 322, 424-428.

(31) Nishi, N.; Yasui, Y.; Uruga, T.; Tanida, H.; Yamada, T.; Nakayama, S.; Matsuoka, H.; Kakiuchi, T. Ionic multilayers at the free surface of an ionic liquid, trioctylmethylammonium bis(nonafluorobutanesulfonyl)amide, probed by x-ray reflectivity measurements. J. Chem. Phys. 2010, 132, 164705.

(32) Panda, B. R.; Chattopadhyay, A. A water-soluble polythiophene-Au nanoparticle composite for pH sensing. J. Colloid Interface Sci. 2007, 316, 962-967.

(33) Pandey, P.; Arya, S. K.; Matharu, Z.; Singh, S. P.; Datta, M.; Malhotra, B. D. Polythiophene gold nanoparticles composite film for application to glucose sensor. J. Appl. Polym. Sci. 2008, 110, 988-994. 
(34) Sanfelice, R. C.; Mercante, L. A.; Pavinatto, A.; Tomazio, N. B.; Mendonca, C. R.; Ribeiro, S. J. L.; Mattoso, L. H. C.; Correa, D. S. Hybrid composite material based on polythiophene derivative nanofibers modified with gold nanoparticles for optoelectronics applications. J. Mater. Sci. 2017, 52, 1919-1929.

(35) Shin, H.-S.; Huh, S. Au/Au@polythiophene core/shell nanospheres for heterogeneous catalysis of nitroarenes. ACS Appl. Mater. Interfaces 2012, 4, 6324-6331.

(36) Lattuada, M.; Hatton, T. A. Synthesis, properties and applications of Janus nanoparticles. Nano Today 2011, 6, 286-308.

(37) Booth, S. G.; Dryfe, R. A. W. Assembly of nanoscale objects at the liquid/liquid interface. J. Phys. Chem. C 2015, 119, 23295-23309.

(38) Poggi, E.; Gohy, J.-F. Janus particles: from synthesis to application. Colloid Polym. Sci. 2017, 295, 2083-2108.

(39) Toth, P. S.; Velicky, M.; Ramasse, Q. M.; Kepaptsoglou, D. M.; Dryfe, R. A. W. Symmetric and asymmetric decoration of graphene: bimetal-graphene sandwiches. Adv. Funct. Mater. 2015, 25, 2899-2909.

(40) Kulkarni, M. M.; Bandyopadhyaya, R.; Sharma, A. Janus silica film with hydrophobic and hydrophilic surfaces grown at an oil-water interface. J. Mater. Chem. 2008, 18, $1021-1028$.

(41) Biswas, K.; Rao, C. N. R. Nanocrystalline Janus films of inorganic materials prepared at the liquid-liquid interface. J. Colloid Interface Sci. 2009, 333, 404-410.

(42) Wang, Q.; Liu, Y.; Qu, X.; Wang, Q.; Liang, F.; Yang, Z. Janus nanosheets by emulsion interfacial crosslinking of reactive surfactants. Colloid Polym. Sci. 2015, 293, 26092615. 
(43) Luo, K.; Xiang, Y.; Wang, H.; Xiang, L.; Luo, Z. Multiple-sized amphiphilic Janus gold nanoparticles by ligand exchange at toluene/water interface. J. Mater. Sci. Technol. 2016, 32, 733-737.

(44) Hong, L.; Jiang, S.; Granick, S. Simple method to produce Janus colloidal particles in large quantity. Langmuir 2006, 22, 9495-9499.

(45) Ji, X.; Zhang, Q.; Liang, F.; Chen, Q.; Qu, X.; Zhang, C.; Wang, Q.; Li, J.; Song, X.; Yang, Z. Ionic liquid functionalized Janus nanosheets. Chem. Commun. 2014, 50, 57065709.

(46) Ji, X.; Zhang, Q.; Qu, X.; Wang, Q.; Song, X.-M.; Liang, F.; Yang, Z. Poly(ionic liquid) Janus nanosheets towards dye degradation. RSC Adv. 2015, 5, 21877-21880.

(47) Guo, P.; Zeng, C.; Wang, C.; Zhang, L. Magnetic ionic liquid-water Janus droplets: preparation, structure and morphology adjustment and magnetic manipulation. AICHE J. 2017, 63, 4115-4123.

(48) Nishi, N.; Murakami, H.; Yasui, Y.; Kakiuchi, T. Use of highly hydrophobic ionic liquids for ion-selective electrodes of the liquid membrane type. Anal. Sci. 2008, 24, 1315-1320.

(49) Earle, M. J.; Gordon, C. M.; Plechkova, N. V.; Seddon, K. R.; Welton, T. Decolorization of ionic liquids for spectroscopy. Anal. Chem. 2007, 79, 758-764.

(50) Yasui, Y.; Kitazumi, Y.; Ishimatsu, R.; Nishi, N.; Kakiuchi, T. Ultraslow response of interfacial tension to the change in the phase-boundary potential at the interface between water and a room-temperature ionic liquid, trioctylmethylammonium bis(nonafluorobutanesulfonyl)amide. J. Phys. Chem. B 2009, 113, 3273-3276.

(51) Kakiuchi, T.; Tsujioka, N.; Sueishi, K.; Nishi, N.; Yamamoto, M. Polarized potential 
window available at the interface between an aqueous electrolyte solution and tetraalkylammonium imide salts. Electrochemistry 2004, 72, 833-835.

(52) Nishi, N.; Imakura, S.; Kakiuchi, T. Wide electrocheical window at the interface between water and a hydrophobic room-temperature ionic liquid of tetrakis[3,5bis(trifluoromethyl)phenyl]borate. Anal. Chem. 2006, 78, 2726-2731.

(53) Nishi, N.; Imakura, S.; Kakiuchi, T. A digital simulation study of steady-state voltammograms for the ion transfer across the liquid-liquid interface formed at the orifice of a micropipette. J. Electroanal. Chem. 2008, 621, 297-303.

(54) Hotta, H.; Akagi, N.; Sugihara, T.; Ichikawa, S.; Osakai, T. Electron-conductor separating oil-water (ECSOW) system: a new strategy for characterizing electron-transfer processes at the oil/water interface. Electrochem. Commun. 2002, 4, 472-477.

(55) Uehara, A.; Hashimoto, T.; Dryfe, R. A. W. Au electrodeposition at the liquid-liquid interface: mechanistic aspects. Electrochim. Acta 2014, 118, 26-32.

(56) Roncali, J. Conjugated poly(thiophenes) - synthesis, functionalization, and applications. Chem. Rev. 1992, 92, 711-738.

(57) Sarac, A.; Evans, U.; Serantoni, M.; Clohessy, J.; Cunnane, V. Electrochemical and morphological study of the effect of polymerization conditions on poly (terthiophene). Surf. Coat. Technol. 2004, 182, 7-13.

(58) Oldham, K.; Myland, J.; Bond, A. Electrochemical science and technology: fundamentals and applications; Wiley: New York, 2011; Chapter 11.

(59) Koryta, J. Electrochemical polarization phenomena at the interface of two immiscible electrolyte solutions - II. Progress since 1978. Electrochim. Acta 1984, 29, 445-452.

(60) Abdou, M.; Holdcroft, S. Oxidation of pi-conjugated polymers with gold trichloride - 
enhanced stability of the electronically conducting state and electroless deposition of $\mathrm{Au}(0)$. Synth. Met. 1993, 60, 93-96.

(61) Ahlskog, M. Stability studies on $\mathrm{AuCl}_{3}$-doped poly(3-hexylthiophene) - comparison with $\mathrm{FeCl}_{3}$ doping. Synth. Met. 1995, 72, 197-200.

(62) Gai, M.; Frueh, J.; Si, T.; Hu, N.; Sukhorukov, G. B.; He, Q. The collision phenomena of Janus polymer micro-plate motors propelled by oscillating micro-bubbles. Colloid Surf. A-Physicochem. Eng. Asp. 2016, 510, 113-121.

(63) Yilmaz, M.; Babur, E.; Ozdemir, M.; Gieseking, R. L.; Dede, Y.; Tamer, U.; Schatz, G. C.; Facchetti, A.; Usta, H.; Demirel, G. Nanostructured organic semiconductor films for molecular detection with surface-enhanced Raman spectroscopy. Nat. Mater. 2017, 16, 918-925.

(64) Toth, P. S.; Velicky, M.; Bissett, M. A.; Slater, T. J. A.; Savjani, N.; Rabiu, A. K.; Rakowski, A. M.; Brent, J. R.; Haigh, S. J.; O’Brien, P.; Dryfe, R. A. W. Asymmetric $\mathrm{MoS}_{2}$ /graphene/metal sandwiches: preparation, characterization, and application. Adv. Mater. 2016, 28, 8256-8264. 


\section{Graphical TOC Entry}

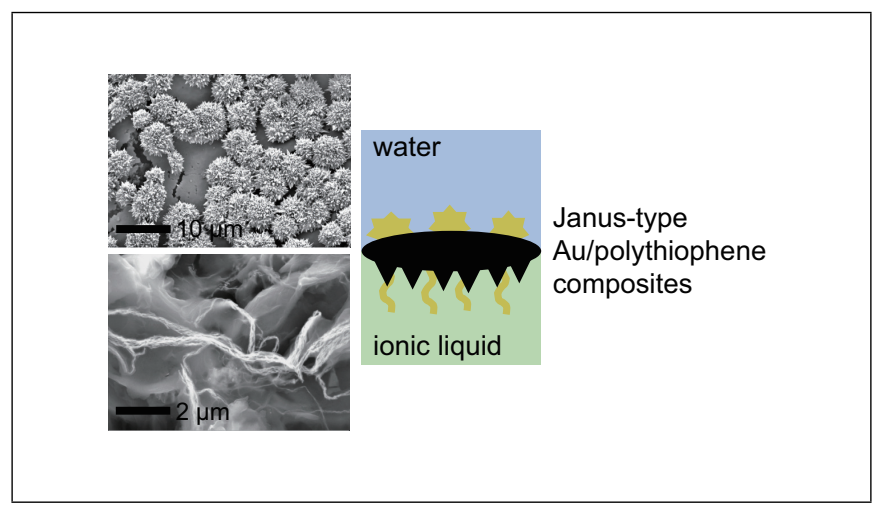

